\title{
MINI-INVASIVE RECONSTRUCTION TECHNIQUE OF THE BULBOMEMBRANOUS URETHRA
}

\author{
${ }^{1}$ Irkutsk State Medical University \\ (ul. Krasnogo Vosstaniya 1, Irkutsk 664003, Russian Federation) \\ ${ }^{2}$ Irkutsk City Clinical Hospital N 1 \\ (ul. Baykalskaya 118, Irkutsk 664046, Russian Federation)
}

\begin{abstract}
The paper presents the technique of the reconstruction of the bulbar and membranous urethra in the occurrence of strictures and sphincter-stenosis. The method uses an autologous graft and has potential advantages over the bulboprostatic anastomosis.

Objective. To develop a method of helping patients with existing urethral anastomoses, with a damaged neck of the bladder and a risk of subsequent incontinence, wishing to maintain the erectile function.

Materials and methods. 35 patients underwent 36 reconstructions of the urethra from August 2013 to July 2017, 11 - after previous urethral plastics, 14 - after prostate surgery (4 - after radical prostatectomy), 7 - suffered from a urethral distraction defect. The age of the patients was $58.17 \pm 12.2$ years. The median follow-up period was 525 (341; 813) days. The average length of urethral strictures was $15(10 ; 15) \mathrm{mm}$. The average diameter of the urethra in the stricture zone was $1.4 \pm 0.56 \mathrm{~mm}$. Reconstruction with the use of a buccal mucosa graft is performed intraurethrally through corpus spongiosum using magnifying optics.

Results. The overall efficacy of the primary reconstruction in 35 patients was $94.2 \%$; the repeated reconstruction in two patients was successful. All patients underwent the comprehensive monitoring of the results, the average follow-up period was 654 days, the average relapse-free period was 447 days. All patients preserved continence and erectile function

Conclusion. The proposed technique showed a high efficiency in reconstruction of the bulbar and membranous urethra.

Key words: bulbar and membranous urethra, urethral stricture, urethral stenosis, bulbo-prostatic anastomosis, buccal mucosal urethroplasty
\end{abstract}

\section{СПОСОБ РЕКОНСТРУКЦИИ БУЛЬБО-МЕМБРАНОЗНОГО ОТДЕЛА УРЕТРЫ}

\author{
Воробъёв В.А. ${ }^{2}$, Бепобородов В.А. ${ }^{1,2}$
}

1 ФГБОУ ВО “Иркутский государственный медицинский университет» Минздрава России (664003, г. Иркутск, ул. Красного Восстания 1, Россия) 2 ОГАУЗ “Иркутская городская клиническая больница № 1" (664046, г. Иркутск, ул. Байкальская, 118, Россия)

Представлен способ реконструкции бульбо-мембранозного отдела уретры при стриктурах и сфинктерстенозах. Метод предполагает использование аутологичного лоскута, имеет потенциальные преимущества в сравнении с бульбо-простатическим анастомозом.

Цель исследования: разработать метод помощи пациентам с несостоятельными уретральными анастомозами, поврежденной шейкой мочевого пузыря и угрозой последующей инконтиненции, а также желающим сохранить эректильную функцию.

Методы. С августа 2013 года по июль 2017 года у 35 пациентов выполнены 36 реконструкций уретры (11 - после предшествующих пластик уретры; 14 - операций на простате, в том числе 4 - после радикальной простатэктомии; 7 - дистракционного дефекта уретры). Возраст пациентов составил от 58,17 12,2 года. Медиана периода наблюдения составила 525 (341; 813) дней.

Средняя протяженность поражений уретры составила $15(10 ; 15)$ мм. Средний диаметр сохранившегося просвета уретры 1,4 $\pm 0,56$ мм.

Реконструкция с использованием трансплантата выполняется трансбульбарно внутриуретрально с использованием увеличительной оптики.

Результаты. Общая эффективность при первичном выполнении у 35 пациентов - 91,4 \%; повторная реконструкция, проведённая двум пациентам, была успешной. Все пациенты прошли комплексный контроль результатов. Средний безрецидивный период - 447 дней. Все пациенты сохранили способность кудержанию мочи. Ухудшений эректильной функции не отмечено.

Заключение. Предложенная методика показала высокую эффективность в восстановлении проходимости проксимальной части бульбарной уретры, бульбо-мембранозного отдела и зон сопоставления после ранее перенесенного бульбо-простатического анастомоза или радикальной простатэктомии. Сохранение кровоснабжения позволило при необходимости успешно выполнить одномоментную реконструкцию стриктур передней уретры. Отсутствие натяжения уретры профилактировало укорочение полового члена, а сохранность дистального мочевого сфинктера - возникновение инконтиненции.

Ключевые слова: бульбо-мембранозный отдел уретры, стриктура уретры, стеноз уретры, бульбо-простатический анастомоз, буккальная пластика уретры

When anastomosing plastics are performed in the proximal bulbous urethra, in the bulbo-membranous part of the urethra, an important criterion of success is its tensionless approximation. Special difficulties arise when the defect removed is more considerable $(4-7 \mathrm{~cm})$. In such cases it is difficult to perform an anastomosis without 
special techniques aimed at a more extensive mobilization of the urethra and straightening its natural curve in the perineum (Webster's techniques). These techniques are traumatizing (instability of the proximal part of cavernous bodies, the intersection of the large vessels of the penis, inferior pubectomy) and lead to a shortening of the penis. In addition, the technique involves the intersection of bulbar vessels, nerves and damage of the structures of the distal urinary sphincter, which can lead to incontinence, erectile dysfunction. There are other less traumatizing techniques (Jordan's operation, etc.), which preserves blood supply, but do not reduce the risk of incontinence. However, they are effective only in cases of unextended lesions (not more than $2.5-3 \mathrm{~cm}$ ).

The initial goal of developing the method proposed by the authors was to create a low-traumatizing method for reconstructing the lumen of the bulbomembranous part of the urethra. The method was planned to be used in the patients who had previously undergone unsuccessful anastomotic operations, and the impossibility of their repeated execution; as well as with iatrogenic strictures of the the bulbomembranous part of the urethra to reduce the risk of incontinence and erectile dysfunction. During the study, we obtained the results demonstrating the possibility of using this method for a wider profile of patients with urethral strictures.

\section{MATERIALS AND METHODS}

In a prospective pilot study, 35 out of 237 patients with confirmed lesions of the bulbous-membranous urethra were included. The one-center study was performed on the basis of Irkutsk City Clinical Hospital N 1 and at the Department of General Surgery of Irkutsk State Medical University from August 2013 to December 2017.

For descriptive statistics of quantitative normally distributed characteristics with variance equality, parametric methods were used: calculation of mean values and standard deviations; for quantitative characteristics with a distribution different from the normal and qualitative order attributes, nonparametric methods were used-the calculation of medians and the corresponding interval between 25 and 75 percentile (Q1; Q3); for qualitative nominal characteristics - relative frequencies in percent. Parametric (where $\mathrm{M}$ is the average of the $\sigma$ data are presented in the form $\mathrm{M} \pm$ is the standard deviation). $\sigma$ arithmetic samples, and nonparametric data are given in the form of a median (Me) and interquartile range (25th and 75 th percentile): Me (25\%, 75\%).

The diagnosis was established on the basis of objective research methods: urethrography, uroflowmetry, urethroscopy. The patient's condition before and after surgery was assessed using IPSS scales, IIEF-5, QoL. In addition, ultrasound examination of the genitourinary system, MRI or MSCT-urethrography was performed. The inclusion criteria were: consent to undergo urethral reconstruction using the developed method and completing all necessary stages of pre- and postoperative examination. The criteria for exclusion were: refusal to participate in the study and the implementation of an alternative method of treatment.

The age of the patients was $58.17 \pm 12.2$ years. The median duration of the disease was $5(1,3 ; 13)$ years. The median follow-up period was $525(341 ; 813)$ days. The average extent of urethral lesions was $15(10 ; 15) \mathrm{mm}$. The average diameter of the urethra is $1.4 \pm 0.56 \mathrm{~mm}$. The obliteration of the urethral lumen was observed in 7 patients.

The incontinence of different intensity was detected before surgery in $17.1 \%$ of cases. Of these, in $50 \%$ of cases, it arose after radical treatment of prostate cancer.

The erectile dysfunction was in 4 patients $(11.4 \%)$. Significantly reduced erectile function (10 or less scores of the IIEF-5) was in 8 patients (22.8\%).

A combination of different affecting factors caused urethral lesions in $62.8 \%$ of cases $(85.7 \%$ - intraurethral mechanical injury, $5.7 \%$ - exposure to aggressive chemical compounds, $28.5 \%$ - radiation exposure or electrocution, external trauma $-37,1 \%$ ). In addition, from the whole group of the patients in $17.1 \%$ of cases there was a pelvic injury, in $28.5 \%$ - a perineal injury with the development of the distraction urethral defect in $53.8 \%$ cases. One patient suffered a trauma during sexual intercourse.

In most cases (77.1\%), patients sought help after some previously surgical treatment of urethral lesions. Characteristics of previous operations: 25 (71.4\%) - one or more internal optical urethrotomy; 11 (31.4\%) - different versions of urethroplastic, 14 (40\%) - after operations on the prostate (including 4 - radical prostatectomy).

Surgical treatment was performed using magnifying optics and urethral retractors. Spinal anesthesia was used as a method of anesthesia. The patient was in the lithotomy position. The incision was made along the median line of the perineum with a length of no more than $4-6 \mathrm{~cm}$. The access was made to the bulbospongiosus muscle layer by layer. The latter was moved along the fibers and a window was formed to the front surface of the corpus spongiosum so as not to separate the muscle along the lateral surfaces of the bulb.

The distal end of the narrowing of the urethra was determined by means of an 18-20 Ch bougie inserted in the external aperture of the urethra. Dissected step-bystep corpus spongiosum and the urethra in the projection of the bulbomembranous physiological curve (Fig. 1). The length of urethrotomy access is 2-3 cm (Fig. 1).

The edges of the urethra were separated with the hooks of Scott retractor or an original urethral retractor. Through the window, a narrowed place in the proximal urethra was visualized (Fig. 2).

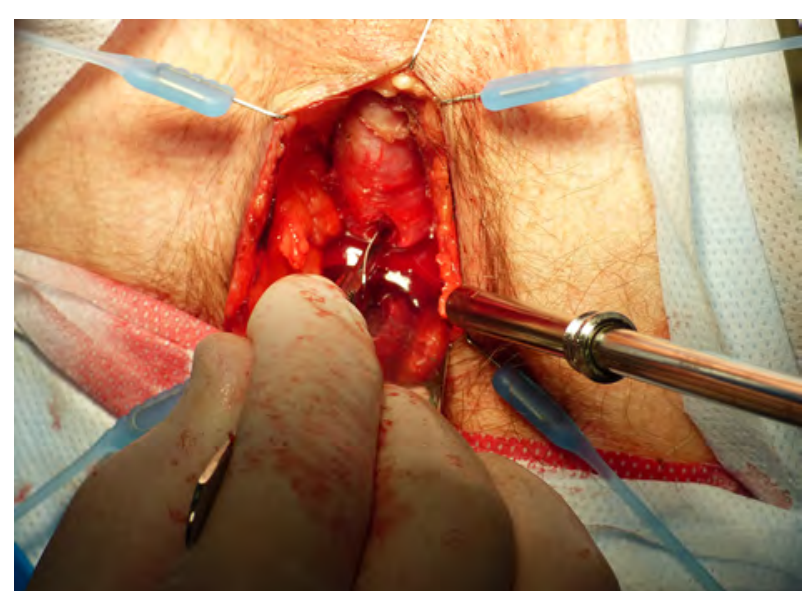

Fig. 1. Urethrotomic access across corpus spongiosum. 


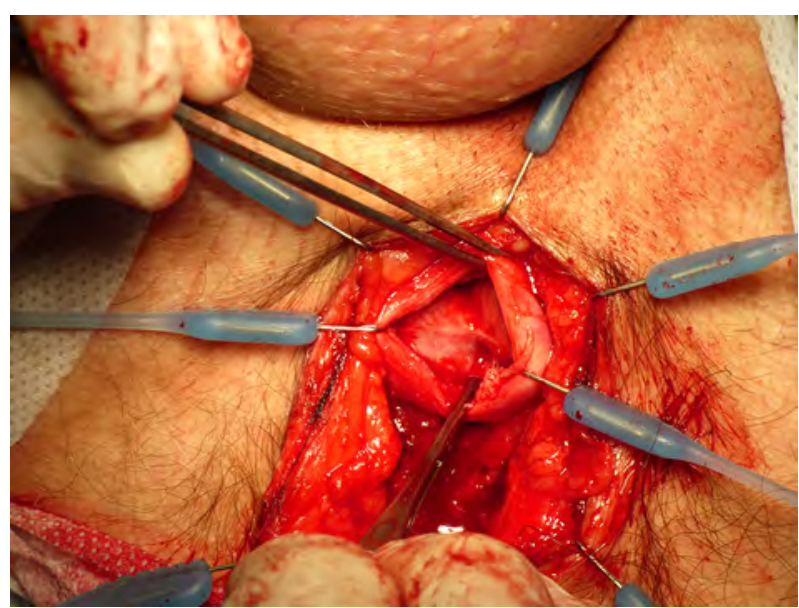

Fig. 2. The stricture of the bulbomembranous part of the urethra, intraoperative view.

The narrowed part of the urethra was dissected ventrally or dorsally with insignificant penetration beyond the urethra into the underlying structures, then the urethral scar tissues were excised (Fig. 3) in the ventral semicircle within 5 to 7 hours of the standard dial. A platform of a diamond-shaped or polyhedral shape with triangular apices for a graft within the excised urethral scar tissue was formed. The proximal and distal boundaries of the formed site should be located within the unchanged urethral tissues. Adequacy of the lumen of the urethra was checked by placing an 18-20 Ch bougie in the bladder.

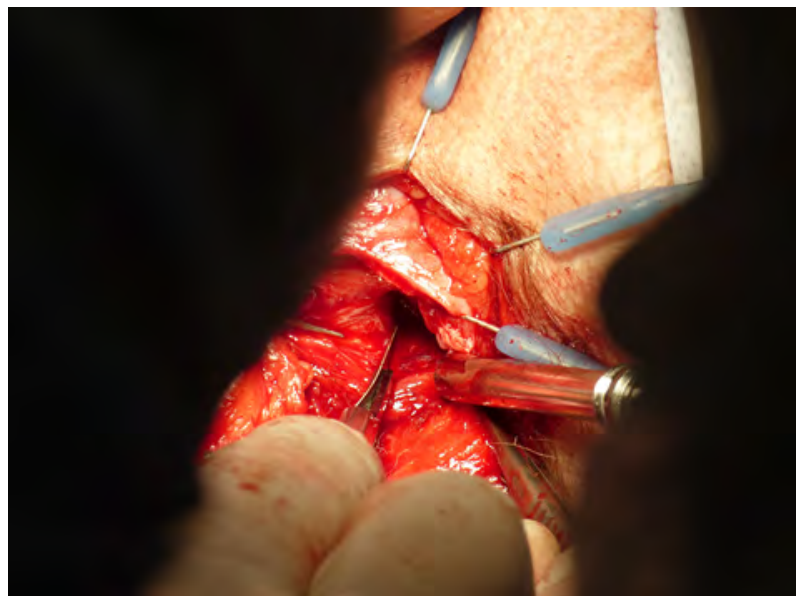

Fig. 3. Excision of scar tissue on ventral part of the urethra.

Buccal mucosal graft (BMG) was used as a transplant. The BMG was removed with a standard procedure. The shape and size of the BMG was selected in accordance with the parameters of the site formed for the graft for the possibility of its placement without tension. The prepared oral flap was fixed in the formed urethral platform (Fig. 4) by successive stitching with separate interrupted stitches (dissolvable suture 4-6/0). The bladder was drained with a Foley urethral catheter - 16-18 Ch. By the technique of the lining (onlay), the distal part of the transplant was stitched and fixed.

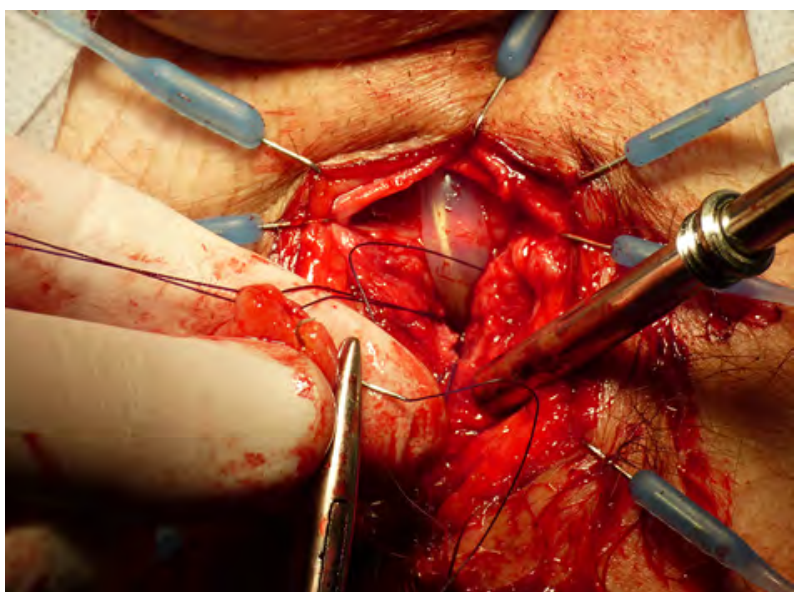

Fig. 4. Fixation of the buccal-mucosa graft.

Urethrotomic access was closed with separate interrupted stitches with stitching the submucous graft layer (in extended lesions) to exclude the formation of a pathological cavity. Drainage of the bladder with a urethral catheter was performed during 10-14 days.

Most patients (82.8\%) were prescribed with the medicine that improve microcirculation for a period of up to one month. In $71.4 \%$ of cases after the operation, hyperbaric oxygenation was performed in the 1-1.5 atmosphere for 40 minutes, $7-10$ sessions (in the absence of contra-indications).

The summary clinical characteristics of patients are presented in Table 1.

Table 1

Clinical characteristics of patients who participated in the research

\begin{tabular}{|l|l|}
\hline Number, people & 35 \\
\hline Age & $59(52,5 ; 66)$ \\
\hline Disease duration, years & $5(1,3 ; 13)$ \\
\hline Follow-up period, days & $525(341 ; 813)$ \\
\hline Concomitant pathology: & \\
\hline BPH & $22(62,8 \%)$ \\
\hline prostate average volume, $\mathrm{cm}^{3}$ & $24,96 \pm 14,19$ \\
\hline $\begin{array}{l}\text { inflammatory diseases of the lower } \\
\text { urinary tract }\end{array}$ & $29(82,8 \%)$ \\
\hline neurogenic urination disorder & $8(22,8 \%)$ \\
\hline \multicolumn{1}{|c|}{ prostate cancer } & $5(14,2 \%)$ \\
\hline bladder cancer & $2(5,7 \%)$ \\
\hline bladder stones & $7(20 \%)$ \\
\hline Cystostomy & $25(71,4 \%)$ \\
\hline Urinary retention & $30(85,7 \%)$ \\
\hline Residual urine volume, $\mathrm{ml}$ & $300(131 ; 547)$ \\
\hline Urethral fistulas & $2(5,7 \%)$ \\
\hline Uroflowmetry, Qmax, $\mathrm{ml} / \mathrm{s}$ & $3(1,17 ; 4,95)$ \\
\hline
\end{tabular}

Note. BPH - benign prostatic hyperplasia.

\section{RESULTS}

In the postoperative period, no complications were detected prior to removal of the urethral catheter. In a 1-3 month period, two patients suffered from acute prostatitis. After removal of the urethral catheter and cystostomic drainage, all of them recovered their own urination. 
The results of the operation were divided into successful and unsuccessful. The success criteria were: Qmax not less than $12 \mathrm{ml} / \mathrm{sec}$, the absence of the signs of the recurrence of the disease according to urethrography, the absence of the residual urine. If these criteria were not met, the result was considered unsuccessful.

The overall effectiveness of the proposed method in its primary implementation was $94.2 \%$ (in 33 out of 35 patients); when repeated - in 2 out of 2 cases (Fig. 5-9).

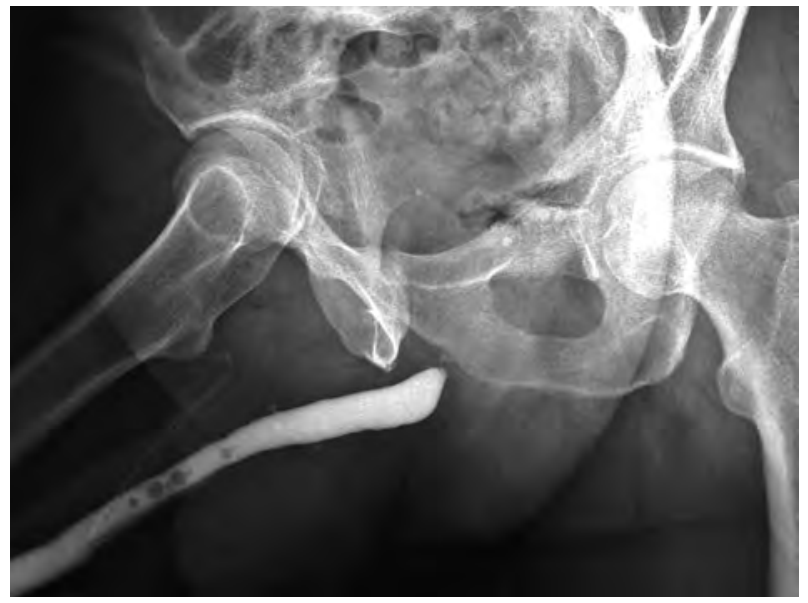

Fig. 5. Patient V., 63 y.o. Urethrography before surgery.

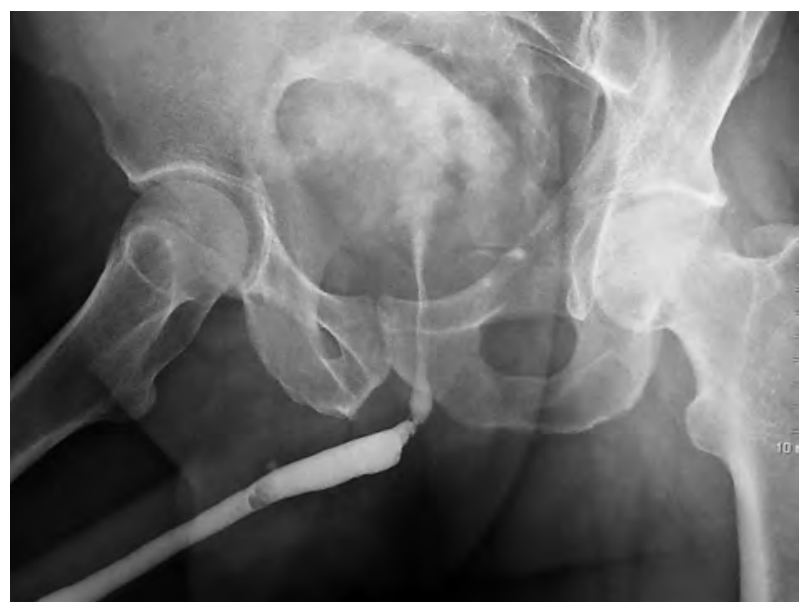

Fig. 6. Patient V., 63 y.o. Urethrography 6 months after surgery.

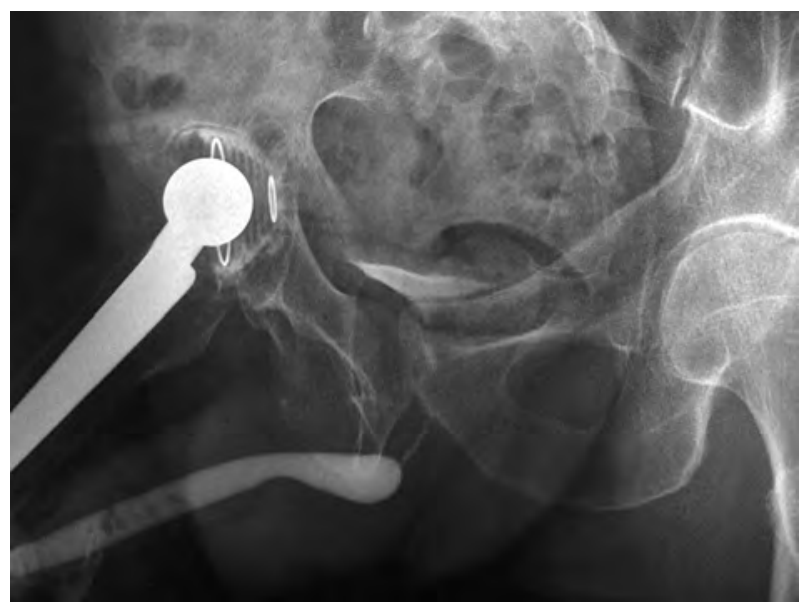

Fig. 7. Patient M., 58 y.o. Urethrography before surgery.

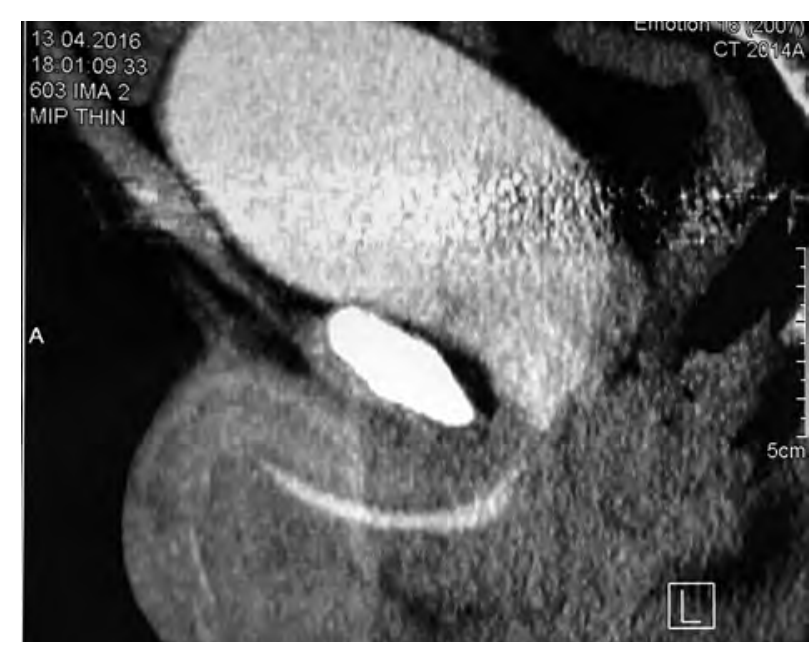

Fig. 8. Patient M., 58 y.o. CT-Urethrography 1 year after surgery (voiding).

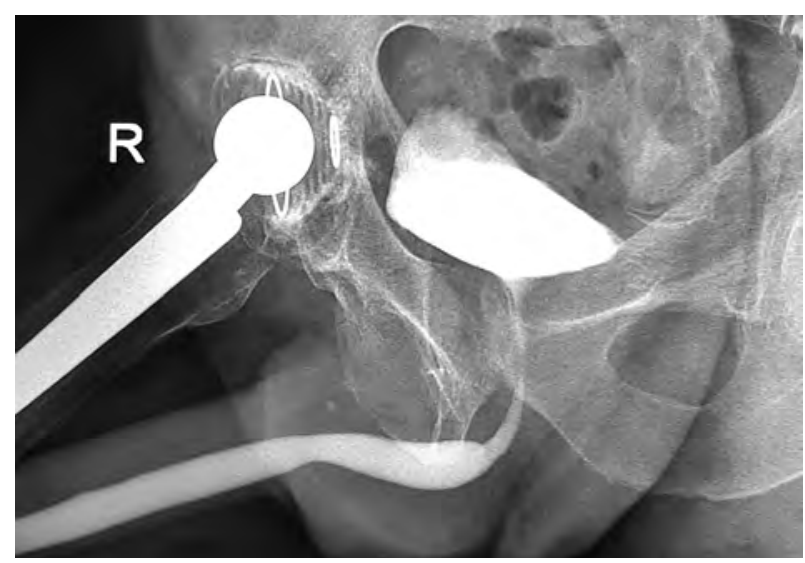

Fig. 9. Patient M., 58 y.o. Urethrography 2 year after surgery (retrograde).

In 4 patients after previous prostatectomy, the reconstruction of the vesicourethral anastomosis was performed by the developed method (Fig. 10-12).

In 14 patients ( $40 \%$ ), the plastic of the stricture of the anterior urethra was additionally carried out simultaneously with an autologous graft. Subsequently, one of them developed a fistula in the penile urethra, eliminated by repeated surgery. Two patients with the replacement of defects of a large extent ( 80 and $175 \mathrm{~mm}$ ) in the penile and bulbar part were successfully performed two-stage plastic.

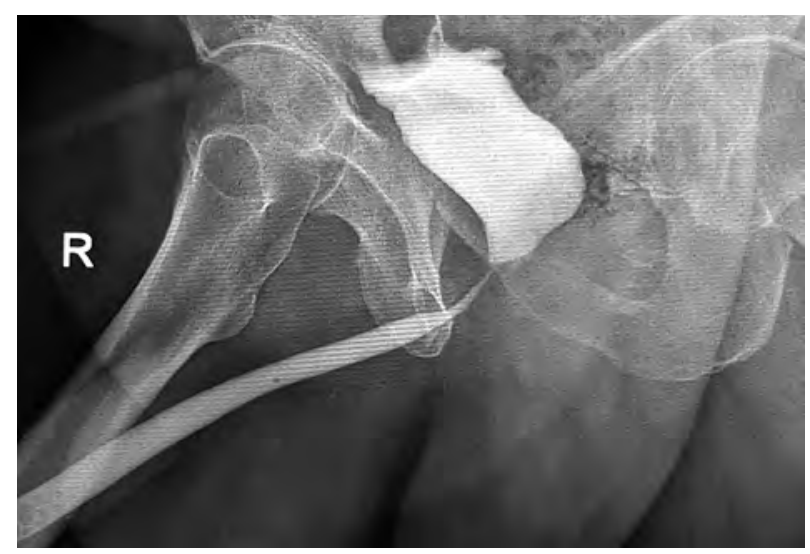

Fig. 10. Patient P., 64 y.o. after prostatectomy. Urethrography before surgery. 


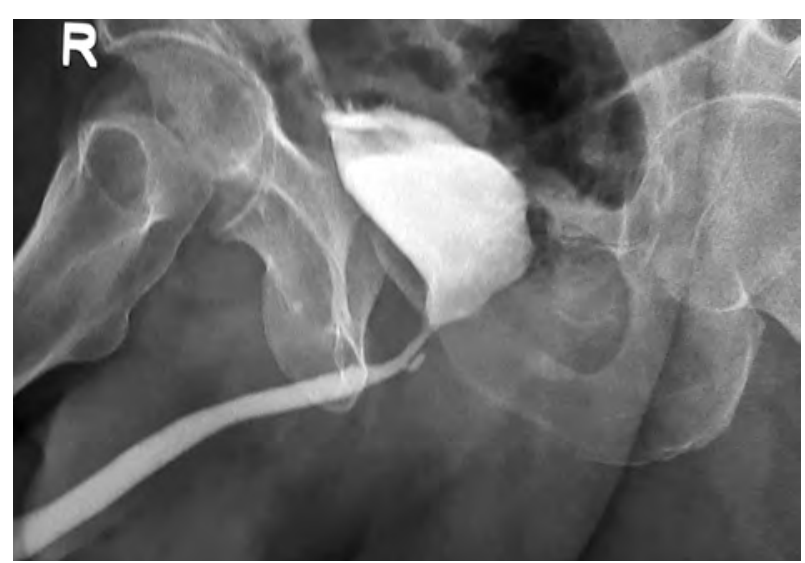

Fig. 11. Patient P., 64 y.o. after prostatectomy. Urethrography 6 month after surgery (retrograde).

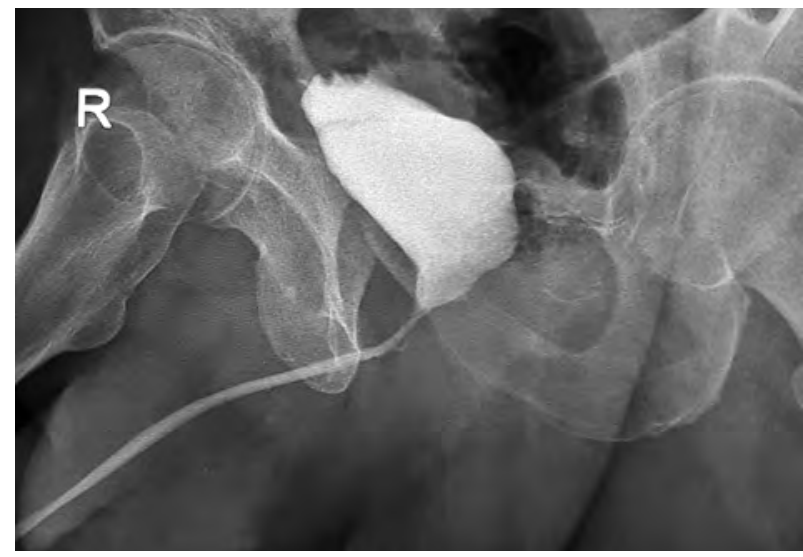

Fig. 12. Patient P., 64 y.o. after prostatectomy. Urethrography 6 month after surgery (voiding).

In 14 patients ( $40 \%$ ), the single-step plastic of the stricture of the anterior urethra with an autologous graft was additionally carried out. Subsequently, one of them developed a fistula in the penile urethra, eliminated by the repeated surgery. Two patients with the replacement of defects of a large extent ( 80 and $175 \mathrm{~mm}$ ) in the penile and bulbar part underwent successful two-step plastic reconstruction.

All patients underwent careful monitoring of the results. The mean follow-up period was 525 (341; 813) days, the average relapse-free period was 389 (126; 647) days. All patients preserved the ability to retain urine. Worsening of erectile function was not noted.

\section{DISCUSSION}

When the proximal part of the bulbous urethra and the bulbomembranous urethral part are affected, two methods of treatment are currently used. The first step is to perform an internal optical urethrotomy with a probable success rate from 30 to $75 \%[5,12,13,18]$. This method is simple, has the greater efficiency in lesions less than $10 \mathrm{~mm}$ in length, and is practically ineffective - at more than two-centimeter length of the pathological process $[4,11,19]$. In this case, the primary and repeated use of this technique can worsen the course of the disease $[6,8]$.

An alternative to the proposed method is one of the methods of anastomotic reconstruction. Traditionally, the bulbomembranous anastomosis (with an intact membranous urethra) is performed with the intersection of the spongy body, a violation of its vascularization and innervation. There are several variants of vessel-sparing methods (Jordan's operation [7], alternative intra-urethral anastomosis of Andrich - Mundy [1]), which allow to avoid violations of the normal blood supply of the corpus spongiosum. All these methods are not practically applicable for lesions more than 2-3 cm.

If the pathological process is located in the proximal zone of the bulbomembranous transition or in the actual membranous part, and also if the overall extent of the lesion is significant, then the effectiveness of the internal optical urethrotomy is critically reduced. At present, the most common and effective (85-98\%) method is the performance of bulbo-prostatic anastomosis [2, 9, 15]. With prolonged lesions, the urethra becomes shorter, and it may be necessary to perform Webster techniques that neutralize the possibility of carrying out anastomosis with the preservation of bulbar vessels. This method can provoke erectile dysfunction and urine incontinence, and shorten the penis [10]. An unpleasant surprise for a surgeon can be a five percent risk of an anastomotic obstruction, even during Webster receptions (dissection of the intercavernosum septum, lower pubectomy, re-rutting) and combined (abdominal-perineal) access [20].

In the case of an extensive distraction defect, urethral strictures more than $7 \mathrm{~cm}$ [17], or ineffectiveness of a one or two-step anastomotic plastic reconstruction [16], it is possible to use a tubularized flap from the perineal skin or other autologous flap, with a low percentage of success. This is due to a violation of the local blood supply and the absence of the revascularizing base for the flaps.

Complications of the treatment of patients with a urinary fistula accompanying stricture of the anterior urethra (in this situation, anastomotic plastics deteriorates the prognosis due to blood supply disturbance of the anterior urethra due to the intersection of bulbar arteries and veins) and previous operations with the damage to the neck of the bladder [7].

Patients who underwent radical prostatectomy constitute a special group. Performing the plastics of the proximal part of the bulbar urethra, the bulbomembranous part or the reconstruction of the vesicourethral anastomosis with its insufficiency in such patients can lead to urinary incontinence, and also reduce the efficiency of the artificial urinary sphincter installation in the future and increase the risk of complications $[3,14]$.

Accordingly, there is a significant group of patients for whom the performance of anastomotic plastics is not the best way out and a method developed by the authors can be proposed as that having several advantages:

1. There is no need for partial or complete mobilization of the bulbous urethra, which allows to preserve vascular and neural pathways, eliminates the risk of urinary incontinence, erectile dysfunction and shortening of the penis.

2. The size of the perineal access is much smaller than when using the previously proposed methods. It is not necessary to supplement access with oblique incisions towards the ischial tuberosity.

3. Unlike skin and revascularized skin grafts, there is no need for multi-stage operations, less cosmetic defect and complexity of the operation.

4. An additional one-stage execution of the plastic stricture of the anterior urethra is possible. 
5. If necessary, the method can be repeated many times before successful outcome without significant damage to the patient's health.

\section{CONCLUSIONS}

The proposed technique showed a high efficiency in restoring the potency of the proximal part of the bulbar urethra, the bulbomembranous section and the matching areas in patients after the bulbo-prostatic anastomosis, radical prostatectomy. The preservation of the blood supply allowed to perform successfully a one-stage plastic reconstruction of the strictures of the anterior urethra. The absence of tension in the urethra prevented from the penis shortening, and the safety of the distal urinary sphincter - the emergence of incontinence.

In connection with the pilot nature of the study, the results presented are preliminary. For a full analysis of the proposed technique, further monitoring of the operated patients is necessary, conducting a multicenter study in a larger sample.

\section{Conflict of interest}

The authors state that there is no conflict of interest.

\section{The transparency of the research}

The study did not have sponsorship. The researchers are fully responsible for providing the final version of the manuscript to the press.

\section{Declaration on financial and other interactions}

All the authors took part in the development of the concept and design of the study and in writing the manuscript. The final version of the manuscript was approved by all the authors. The authors did not receive a fee for the research.

\section{REFERENCES}

1. Andrich DE, Mundy AR. (2012). Non-transecting anastomotic bulbar urethroplasty: a preliminary report. BJU Int, 109 (7), 1090-1094. doi:10.1111/j.1464410X.2011.10508.x.

2. Corriere JN. (2001). 1-Stage delayed bulboprostatic anastomotic repair of posterior urethral rupture: 60 patients with 1-year followup. J Urol, 165 (2), 404-407.

3. Guralnick ML, Miller E, Toh KL, Webster GD. (2002). Transcorporal artificial urinary sphincter cuff placement in cases requiring revision for erosion and urethral atrophy. J Urol, 167 (5), 2075-2078; discussion 2079.

4. Hafez AT, El-Assmy A, Dawaba MS, Sarhan 0, Bazeed M. (2005). Long-term outcome of visual internal urethrotomy for the management of pediatric urethral strictures. J Urol, 173 (2), 595-597.

5. Heyns CF, Steenkamp JW, De Kock ML, Whitaker P. (1998). Treatment of male urethral strictures: is repeated dilation or internal urethrotomy useful? JUrol, 160 (2),356-358.

6. Hudak SJ, Atkinson TH, Morey AF. (2012). Repeat transurethral manipulation of bulbar urethral strictures is associated with increased stricture complexity and prolonged disease duration. J Urol, 187 (5), 1691-1695. doi:10.1016/j.juro.2011.12.074.

7. Jordan GH, Eltahawy EA, Virasoro R. (2007). The technique of vessel sparing excision and primary anastomosis for proximal bulbous urethral reconstruction. $J$ Urol, 177 (5), 1799-1802.

8. Jordan GH, Wessells H, Secrest C, Squadrito JF Jr., McAninch JW, Levine L, van der Burght M; United States Study Group. (2013). Effect of a temporary thermo-expandable stent on urethral patency after dilation or internal urethrotomy for recurrent bulbar urethral stricture: results from a 1-year randomized trial. J Urol, 190 (1), 130-136. doi: 10.1016/j.juro.2013.01.014.

9. Koraitim MM. (2014). Optimising the outcome after anastomotic posterior urethroplasty. Arab J Urol, 13 (1), 27-31. doi: 10.1016/j.aju.2014.12.006.

10. Koraitim MM. (2012). Unsuccessful outcomes after posterior urethroplasty: definition, diagnosis, and treatment. Urology, 79 (5), 1168-1173. doi:10.1016/j. urology.2011.11.078.

11. Kumar S, Kapoor A, Ganesamoni R, Nanjappa B, Sharma V, Mete UK. (2012). Efficacy of holmium laser urethrotomy in combination with intralesional triamcinolone in the treatment of anterior urethral stricture. Korean J Urol, 53 (9), 614-618. doi: 10.4111/kju.2012.53.9.614.

12. Launonen E, Sairanen J, Ruutu M, Taskinen S. (2014). Role of visual internal urethrotomy in pediatric urethral strictures. J Pediatr Urol, 10 (3), 545-549. doi: 10.1016/j.jpurol.2013.11.018.

13. Mouraviev VB, Coburn M, Santucci RA. (2005). The treatment of posterior urethral disruption associated with pelvic fractures: comparative experience of early realignment versus delayed urethroplasty. J Urol, 173 (3), 873-876.

14. Mundy AR. (1989). The treatment of sphincter strictures. Br J Urol, 64 (6), 626-628.

15. Mundy AR. (1996). Urethroplasty for posterior urethral strictures. Br J Urol, 78 (2), 243-247.

16. Mundy AR, Andrich DE. (2011). Urethral trauma. Part II: Types of injury and their management. BJU Int, 108 (5), 630-650. doi: 10.1111/j.1464-410X.2011.10340.x.

17. Oosterlinck W, Lumen N, Van Cauwenberghe G. (2007). [Surgical treatment of urethral stenoses: technical aspects]. Ann Urol (Paris), 41 (4), 173-207.

18. Steenkamp JW, Heyns CF, de Kock ML. (1997). Internal urethrotomy versus dilation as treatment for male urethral strictures: a prospective, randomized comparison. J Urol, 157 (1), 98-101.

19. Zehri AA, Ather MH, Afshan Q. (2009). Predictors of recurrence of urethral stricture disease following optical urethrotomy. Int J Surg, 7 (4), 361-364. doi: 10.1016/j. ijsu.2009.05.010.

20. Webster GD, Ramon J, Kreder KJ. (1990). Salvage posterior urethroplasty after failed initial repair of pelvic fracture membranous urethral defects. J Urol, 144 (6), 1370-1372.

\section{Information about the authors}

Vorobyev Vladimir Anatolievich - Urologist at the Urology Unit, Irkutsk City Clinical Hospital N 1 (664046, Irkutsk, ul. Baykalskaya, 118, e-mail: terdenecer@gmail.com) (1) http://orcid.org/0000-0002-3299-1924

Beloborodov Vladimir Anatolievich - Doctor of Medical Sciences, Professor, Head of the Department of General Surgery, Irkutsk State Medical University (664003, Irkutsk, ul. Krasnogo Vosstaniya, 1; tel. (3952) 24-38-25; e-mail: bva555@yandex.ru) (10 http:// orcid.org/0000-0003-3285-5559 